\title{
Socio-Demographic Determinants of Place of Delivery among Women of Reproductive Age (15- 49 Years) Seeking Child Welfare Services in Kandara Subcounty, Murang'a
}

\author{
Gachathi Daniel Muya ${ }^{1}$, Okova Rosemary ${ }^{2}$, Mwangangi Francisca ${ }^{3}$ \\ ${ }^{1}$ MurangaCounty Government \\ ${ }^{2,3}$ Mount Kenya University
}

\begin{abstract}
Maternal and child mortalities are among major health problems facing developing countriesincluding Kenya. Most of these deaths can be avoided by utilization of maternity healthcare services by women seeking delivery care services from health professionals. The main objective of the study was to assess the socio-demographic determinants that influence the place of delivery among mothers seeking Child Welfare services in sampled health facilities in Kandara Sub County. The study adopted a facility-based cross-sectional survey design using an interview schedule and Key Informant Interview (KII) to collect quantitative and qualitative data respectively. The researcher pretested data tools in three health facilities that did not participate in the final study. On ethical issues, the researcher was cleared by the University Ethics Committee and by the administration of Murang'a County and of Kandara Sub County. The researcher ensured respondents privacy, confidentiality and anonymity throughout the entire research process. The study population comprised of mothers recently delivered within a 12 month prior to the study and seeking Child Welfare services at the selected health facilities in the Sub County. Simple random and purposeful sampling methods were used to identify the facilities which participated in the study. The desired sample size was 352 respondents which wascalculated using Fishers et al 1998 formula. Respondents were identified using systematic random sampling method. Descriptive statistic was used to represent analyzed data. A Computer software, Statistical Package for Social Sciences (SPSS) version20.0was used to analyze the quantitative data. Content analysis Qualitative data done and results triangulated with the quantitative data as per the study variables. The study found that social demographic determinants( $p$ value of 0.034) had a significant positive influence on the choice of place of delivery.
\end{abstract}

Keywords: Child welfare services, place ofdelivery, Mother, Maternal,Mortality,Morbidity,Safe Motherhood

\section{Introduction}

Globally half a million women die from pregnancy and childbirth related complications every year of which over $90 \%$ of these deaths occur in developing countries (Oguntundeet al., 2010).

In Africa and Asia, approximately 536,000 women die from complications related to pregnancy and childbirth, with $99 \%$ of these deaths taking place (WHO, 2008).

In Kenya, an estimated 7,700 women die each year as a result of pregnancy-related causes (Republic of Kenya, 2010). The fourth $\left(4^{\text {th }}\right)$ and fifth $\left(5^{\text {th }}\right)$ MDGs were geared to reducing the Child Mortality rate and Improving the Maternal Health respectively by the year 2015(UN, 2007).A measure of the proportion of deliveries assisted by skilled attendants and maternal mortality ratio(MMR) are the indicators of progress towards achieving MDG numbers 4 and 5 (UN, 2007).

A Study by the Kenya National Bureau of Statistics (KNBS 2010) indicates that 43 percent of births in Kenya take place in health facilities, while 56 percent of births take place at home.

The study showed that the proportion of children born at home decreases as level of education and wealth quintile of the mother increase (KNBS, 2010). According to Kenya
Service Provider and Assessment Survey (KSPAS), for Kenya to reduce high maternal mortality and morbidity rates, societal and cultural determinants that affect women's health and their access to services should beadequately addressed (KSPAS, 2008).

According to Kenya Demographic and Health Survey (KDHS 2008/09), increasing the proportion of women that deliver in health facilities reduces the health risks to both the mother and thebaby. These deaths could have been prevented with adequate medical care during and after delivery (MOPHS, 2008

"The safe motherhood initiative" was launched in Nairobi in 1987 (Starrs, 2006) and its aim was to create awareness about the numbers of women dying each year from complications of pregnancy and childbirth, and also to challenge amelioration of the situation.

\section{Problem Statement}

According to KDHS 2014, Maternal Mortality Rate (MMR) of 362/100,000 has been reported this is a decrease from the 2009 survey which was at 448/100,000 live birth in Kenya.

More than $90 \%$ of women in Kenya already attend prenatal clinics in health facilities but only about $60 \%$ deliver at the hospital (KNBS 2010). This could partly be attributed to the place of delivery especially due to unskilled deliveries as 


\section{International Journal of Science and Research (IJSR) \\ ISSN (Online): 2319-7064 \\ Index Copernicus Value (2015): 78.96 | Impact Factor (2015): 6.391}

only 60 percent of births take place under skilled personnel (KDHS 2014).

According to the DHIS 2014, skilled deliveries in Murang'a County for 2014 financial year was 13820 (61.3\%) out of expected 22,560 deliveries that year. In Kandara SubCounty there were 1315 (35\%) skilled deliveries reported in 2014 financial year. This is far below the main aim of MDGs which is to increase the proportion of deliveries attended by skilled birth attendants to $90 \%$ worldwide by the year 2015 (UNFPA, 1999).

Stephenson et al. (2006) also found that Marital status, maternal age and religion to be important determinants of place of delivery in Kenya

In this regard, more studies ought to be carried out in order to find out how the socio-demographic determinants influence the choice of place of delivery among WCBA in the study area hence reducing child mortality and improve maternal health.

\section{Justification of Study}

To achieve MDGs number four and five, on reduction of child and maternal mortality,deliveriesshould take place under the supervision of skilled attendants. Despite the low number of skilled deliveries reported (35\%) in the sub county, $99.9 \%$ of babies were taken to health facilities for child welfare services in the same period (DHIS, 2014).8 77

The purpose of this study was to assess the sociodemographic determinants that influenced the place of delivery among women of child bearing age no otherstudy has been done in the study area.

The information that the study generated will be used by stakeholders working with maternal and child health in the Sub County to make informed decisions and polices that will address the determinants influencing the choice of place of delivery among Women of Child Bearing Age.

\section{Materials and Methods}

A facility based cross sectional descriptive study design was used.

The study area was Kandara Sub County which is one of the seven Sub Counties in Murang'a County covering an area of $234 \mathrm{~km}^{2}$ and is situated $45 \mathrm{~km}$ north of Nairobi city. The area has a good road communication network with tarmac and Murom roads. The main economic activity is small crop farming and animal rearing. There are small scale businesses in the few shopping centers in the Sub County.

Health facilities are distributed as: 23 GOK facilities, 5 Faith Based Facilities and 4 private health facilities.

The target population in this study was Women of Child Bearing Age (18-49years) seeking child welfare services at Kandara Sub County health facilities. The monthly average workload of WCBA in the Sub County is 4,158 .
The study population was Women of Child Bearing Age (18-49years) seeking child welfare services at Kandara Sub County health facilities.

Seventeen (16 facility in-charges and 1 Sub County Public Health Nurse) were interviewed using Key Informant Interview guide.

Mothers who had given birth within the last 1 year seeking Child Welfare services at the time of the study in selected health facilities in Kandara Sub County and of sound mind

Excluded from the study wereMothers whose age was below18 years and beyond 49 Mothers of unsound mind, mothers who had delivered more than 12 months prior to the study andMothers who had not lived in the area for the last one year (visitors)

Dedependent variable -Choice of Place of delivery was the dependent variable

Independent variable-Socio -demographic characteristics

Table 1: Measurement of Variables

\begin{tabular}{|c|c|c|}
\hline \multicolumn{2}{|c|}{ Independent variables } & Measurement \\
\hline \multirow{10}{*}{$\begin{array}{c}\text { Socio } \\
\text { demographic }\end{array}$} & Age & $\begin{array}{l}\text { Number of complete years lived by } \\
\text { the respondent from the time she } \\
\text { was born. }\end{array}$ \\
\hline & Marital status & Attachment to a husband \\
\hline & Education level & $\begin{array}{l}\text { The highest schooling level } \\
\text { achieved by the respondent }\end{array}$ \\
\hline & Occupation & $\begin{array}{l}\text { Main source of livelihood of both } \\
\text { the woman }\end{array}$ \\
\hline & Income & $\begin{array}{c}\text { Mean monthly income of the } \\
\text { mother in Kenya shillings. }\end{array}$ \\
\hline & Religion & $\begin{array}{l}\text { Belief, faith, conviction whether } \\
\text { Christian or Muslim or any other } \\
\text { denomination. }\end{array}$ \\
\hline & $\begin{array}{c}\text { Number of } \\
\text { children }\end{array}$ & $\begin{array}{l}\text { Number of babies ever born by the } \\
\text { respondent whether alive or dead }\end{array}$ \\
\hline & Danger signs & $\begin{array}{l}\text { Mentioning the danger signs in } \\
\text { relation to complications of } \\
\text { pregnancy and process of delivery. }\end{array}$ \\
\hline & Time & $\begin{array}{c}\text { Moment spent in seeking maternity } \\
\text { services in hours }\end{array}$ \\
\hline & Cost & $\begin{array}{l}\text { Charges incurred in relation to } \\
\text { maternity services in Kenya } \\
\text { shillings. }\end{array}$ \\
\hline \multicolumn{3}{|c|}{ Dependent variable } \\
\hline \multicolumn{2}{|c|}{ Place of delivery } & $\begin{array}{l}\text { The actual site where the mother } \\
\text { gave birth to her baby. }\end{array}$ \\
\hline
\end{tabular}

\section{Sample size determination}

Sample size was calculated using the Fishers et al., 1998 formula (cited by Mugenda\&Mugenda, 2003).The desired sample size was 352 respondents.

Reliability Analysis findings indicated that socialdemographic characteristics had a coefficient of 0.747 value of Cronbach'sAlpha above the suggested value of 0.5 thus the study was reliable (Nunnally and Bernstein, 1994; Nunnally, 1974). 
International Journal of Science and Research (IJSR)

ISSN (Online): 2319-7064

Index Copernicus Value (2015): 78.96 | Impact Factor (2015): 6.391

\section{Results}

\section{Respondents' Marital Status}

Table 1: Respondents' Marital Status

\begin{tabular}{|c|c|c|}
\hline Marital status & Frequency & Percent \% \\
\hline Married & 229 & 79.9 \\
\hline Single & 41 & 14.6 \\
\hline Separated/divorced & 17 & 5.6 \\
\hline Total & $\mathbf{2 8 7}$ & $\mathbf{1 0 0 . 0}$ \\
\hline
\end{tabular}

Majority $229(79.9 \%$ (95\% confidence interval $=75.2 \%$ $84.6 \%)$ ) of the respondents were married while $41(14.6 \%$ $(95 \%$ confidence interval $=10.5 \%-18.7 \%))$ and $17(5.6 \%$ $(95 \%$ confidence interval $=2.9 \%-8.3 \%))$ were single and separated/divorced respectively. This sample therefore had a statistically significant higher proportion of married women compared to those who were either divorced or single (Table 1).

Table 2: Main Source of Income

\begin{tabular}{|c|c|c|}
\hline Source of Income & Frequency & Percent \% \\
\hline Rely on husband/partner & 112 & 39.3 \\
\hline Business /self employed & 77 & 26.9 \\
\hline Temporary /casual work & 54 & 18.9 \\
\hline Employed /salaried & 21 & 7.4 \\
\hline Rely on parents & 20 & 7.4 \\
\hline Total & $\mathbf{2 8 7}$ & $\mathbf{1 0 0 . 0}$ \\
\hline
\end{tabular}

Over a third $112(39.3 \%$ (95\% confidence interval $=33.6 \%$ $45.0 \%$ ) of the respondents relied on their husbands/partner for financial support while slightly over a quarter $77(26.9 \%$ $(95 \%$ confidence interval $=21.8 \%-32 \%)$ ) had businesses/self-employed. A small proportion $21(7.4 \%$ $(95 \%$ confidence interval $=4.5 \%-10.3 \%)$ was employed /salaried with an equal proportion $20 \quad(7.4 \% \quad(95 \%$ confidence interval $=4.5 \%-10.3 \%$ ) ) relying on their parents for financial support. The KII revealed that socio demographic characteristics have little influence on the choice of place of delivery among expectant mothers in the Sub County.

\section{Respondents' Level of Education}

About a half 140 (48.9\%) (95\% confidence interval $=43.0 \%$ - 54.8\%) of the respondents had attained primary level education while more than a third 105 (36.8\%) $(95 \%$ confidence interval $=31.3 \%-45.9 \%)$ had secondary level education. Five percent 15 (5.3\% (95\% confidence interval = $2.8 \%-7.8 \%)$ ) of the respondent had no formal education. Only $3(1 \%)$ of the respondents had attained university level education. The findings are as presented in Table 6.

Table 3: Respondents' Level of Education

\begin{tabular}{|c|c|c|}
\hline Education level & Frequency & Percent \% \\
\hline No formal education & 15 & 5.3 \\
\hline Primary level & 140 & 48.9 \\
\hline Secondary level & 105 & 36.8 \\
\hline College level & 24 & 8.7 \\
\hline University level & 3 & .3 \\
\hline Total & $\mathbf{2 8 7}$ & $\mathbf{1 0 0 . 0}$ \\
\hline
\end{tabular}

\section{Discussions}

The research findings revealed that (48.9\%) of the respondents in this study had attained primary level of education. Women who had attained more education level preferred delivering in hospitals than at home. Seventy nine (79.9\%) of women who were married delivered in hospitals this could be attributed to an assured support from their husbands. $(39.3 \%)$ of the women under study relied on their husband for financial support. This was a major hindrance to deliver in hospitals for women who relied on their husbands for funds.

This findings complements the findings of Gabrysch et al. (2011), who argues that individual determinants including maternal age, parity, education and marital status, household determinants including family size, household wealth, and community determinants including available health facilities, distance to health facilities, socioeconomic status, community health infrastructure, region and rural/urban residence were noted as determinants of place of delivery these determinants were found to interact in diverse ways in each context to determine place of delivery in Rural Zambia.

\section{Conclusion}

The study sought to establish how socio demographic determinants influence the place of delivery among mothers Sub-County.

The study was conducted at Kandara Sub-County health facilities in Muranga County. The study adopted a facility based crossed sectional descriptive study with intention to assess the determinants that influenced the choice of place of delivery among mothers. A sample of 323 respondents was selected using random purposive sampling approach. This research relied on primary data which was collected using a semi-structured questionnaire and key inter-view informant guides which contained open ended and close ended questions. Cronbach Alpha Coefficients were obtained to establish the reliability of data. The coefficients were above the required 0.7 hence noedmal.

The objective of this study was to establish the determinants of choice of place of birth among women of child bearing age seeking child welfare services in Kandara Sub-County, Muranga County. The study findings indicate that there is a significant positive effect on choice of place of birth and the determinants under study namely: Socio-demographic characteristics

\section{Recommendations}

This study is a justification that the determinants under study have a significant positive effect on choice of place of birth for women of child bearing age seeking child welfare services from Kandara Sub-County, Murang'a County. With due regard to the ever increasing desire to have high skilled deliveries in Kenya, Women of child bearing age should be sensitized on the essence of attending anti-natal clinics and to deliver in hospitals This will go a long way in enlightening women them on the risks of delivering at home.

\section{Volume 6 Issue 7, July 2017 www.ijsr.net}




\section{International Journal of Science and Research (IJSR) \\ ISSN (Online): 2319-7064}

Index Copernicus Value (2015): 78.96 Impact Factor (2015): 6.391

Since Women who had attained education level and married woman preferred delivering in health facility than at home. Focus should therefore be on women with lower level of education and the single mothers. Those who relied on their husbands for financial support were more likely to deliver at home. This emphasizes on the $1^{\text {st }}$ delay in seeking health care and the need to address it to achieve better SBAdelivery.

\section{Recommendations for Further Research studies}

This study is a milestone for future research in this area, particularly in the maternal health sector. First, this study focused on determinants of place of birth in Kandara SubCounty, Muranga County and therefore, generalizations cannot adequately be extended to other Counties. Based on this fact among others, it is therefore, recommended that a broad based study covering several Counties in Kenya be done to find out the extent to which social determinants influence the choice of place of birth among WRA.

\section{References}

[1] District health Information Software Kenya (DHIS 2014). Murang'a Gabrysch S, Cousens S, Cox J, Campbell (2011). Distance and quality of care strongly influence choice of delivery place in rural Zambia: A study linking national data in a Geographic Information System. J Epidemiol Community health 2011, 65:A42A42.

[2] Kenya National Bureau of Statistics (KNBS) and ICF Macro (2010).Kenya Demographic and Health Survey 2008-09. Calverton, Maryland: KNBS and ICF Macro.

[3] Kenya National Bureau of Statistics, Ministry of Health, O. R. C. Macro (2009).Kenya 18 Demographic and Health Survey 2008 report. Calverton, Maryland, USA; 2009

[4] Kenya Service Provider and Assessment Survey (2006).KSPAS Maternal and Child health, Family planning and Sexually Transmitted Infections. National Coordination Agency for population and Development, $\mathrm{MOH}, \mathrm{CBS}$, ORC, Macro USA: USAID, UNICEF, DFID;

[5] Kenya Demographic and Health Survey (2008/09). Calverton, Maryland: Kenya National Bureau of statistics and ICF Macro: 2010.

[6] Kenya Demographic and Health Survey (2014). Calverton, Maryland: Kenya National Bureau of statistics and ICF Macro: 2014.

[7] Ministry of Public Health and Sanitation (2008).Annual Health Sector Statistics. [http://www.publichealth.go.ke] accessed on 29/09/2014.

[8] Mugenda O., and Mugenda A., (2003).Research methods; qualitative and quantitative approaches. Act Press; Nairobi

[9] Nunnally, J.C. (1978). Psychometric Theory. New York; McGraw-Hill-USA

[10] Oguntunde O. O., AinaM.S.,Ibrahim, H.S.Umarand P. Passano (2010). Antenatal care and skilled birth attendance in three communities in Kaduna state.Nigeria. Afr.J. Reprod.Health,14(3):89-96.

[11] Republic of Kenya (2010).National Roadmap for Accelerating the Attainment of MDGs related to Maternal and Newborn health in Kenya.Ministry of
Health, Central Bureau of Statistics, Macro International; Nairobi, Kenya.

[12] Starrs A. (2006). Safe motherhood: 20 years and counting. Lancet 2006, 368:1130-1133.

[13] Stephenson R., Baschieri A., Clements S., Hennik M., Madise N. (2006). Contextual influences on the use of health facilities for childbirth in Africa. Am J., Public Health .96(1);84-93.doi:10.2015/AJPH.2004.057422.

[14] United Nations (2007).The Millennium Development Goals report: Statistical annex. New York.

[15] United Nations Population Fund (1999).UNFPA Key actions for the further implementation of the Programme of Action of the International Conference on Population and Development.Adopted by the Twenty-first Special Session of the United Nations General Assembly. New York: UNFPA:64.

[16] World Health Organization (2008).Trends in Maternal Mortality: 1990 to 2008. Geneva: WHO, UNICEF, UNFPA \& the World Bank

[17] World Health Organization, UNICEF and UNFPA/WB (2008).Maternal mortality in 2005: estimates developedby WHO, UNICEF, UNFPA and World bank. Geneva, Switzerland.

[18] World Health Organization (2008).Proportion of births attended by a skilled health worker.[http://www.who.int/reproductivehealth/ publications/maternal perinatal health/ 2008_skilled_attendant.pdf] Geneva, Switzerland: WHO; 2008

[19]First author-Gachathi Daniel Muya ,MSCN (MIDWIFERY) nursing officer MurangaCounty government, Kenya email;destiny.gachathi@gmail.com telephone- +254721896314

[20] Second author- DrOkovaRosemary. PHD NURSING, LECTURER MOUNT KENYA UNIVERSITY DEPARTMENT OF LEADERSHIP AND RESEARCH email; rokova@mkku.ac.ke phone +25411518395

[21] Third author- MwangangiFrancisca Masters of Public Health, LECTURERMOUNT KENYA UNIVERSITY,email: fmwangangi@mku.ac.ke phone+254 indicate the phone number 